\title{
Morpho-agronomic and qualitative performance of various FCV tobacco exotic hybrids
}

Muhammad Rabnawaz Khan ${ }^{1 *}$, Kamal Shah ${ }^{2}$, Muhammad Zahid ${ }^{2}$, Muhammad Noman Khan ${ }^{3}$, Muhammad Zahir Afridi ${ }^{2}$, Sarmad Iqbal ${ }^{2}$, Syed Minhaj Ali Shah ${ }^{2}$, Rashid Ullah ${ }^{2}$ and Syed Junaid Ahmad ${ }^{2}$

1. Department of Agronomy, Faculty of Crop Production Sciences, The University of Agriculture, PeshawarPakistan

2. Department of Agronomy, Faculty of Crop Production Sciences, AMK Campus Mardan, The University of Agriculture, Peshawar-Pakistan

3. Department of Horticulture, Faculty of Crop Production Sciences, AMK Campus Mardan, The University of Agriculture, Peshawar-Pakistan

*Corresponding author's email: rabnawazagri@gmail.com

Citation

Muhammad Rabnawaz Khan, Kamal Shah, Muhammad Zahid, Muhammad Noman Khan, Muhammad Zahir Afridi, Sarmad Iqbal, Syed Minhaj Ali Shah, Rashid Ullah and Syed Junaid Ahmad. Morpho-agronomic and qualitative performance of various fcv tobacco exotic hybrids. Pure and Applied Biology. Vol. 6, Issue 3, pp942-947. http://dx.doi.org/10.19045/bspab.2017.60099

Received: 02/02/2017

Revised: 20/07/2017

Accepted: 26/07/2017

Online First: 30/07/2017

\section{Abstract}

A filed experiment on "Morpho-agronomic and qualitative performance of various FCV tobacco exotic hybrids" was conducted at the Tobacco Research Station Khan Garhi Mardan during the year of 2014-2015. The experiment was designed in randomized complete block design with three replications. Ten (10) FCV tobacco hybrids (PVH-2310, PVH-2275, PVH-2233, PVH2261, CSC-4302, CSC-444, CSC-447, CSC-4703, SPT-G-28 and K-399) were sown. The parameters studied were plant height $(\mathrm{cm})$, number of leaves plant ${ }^{-1}$, leaf Area $\left(\mathrm{cm}^{2}\right)$, no. of green leaves $\mathrm{kg}^{-1}$, no. of cured leaves $\mathrm{kg}^{-1}$, cured leaf yield $\left(\mathrm{kg} \mathrm{ha}^{-1}\right)$, reducing sugar content $(\%)$ and nicotine content $(\%)$. The studied tobacco hybrids exhibited highly significant differences for all the parameters recorded. The hybrid PVH-2310 performed best among the studied hybrids and comparatively provided the maximum values for plant height $(131.8 \mathrm{~cm})$, no. of leaves plant ${ }^{-1}$ (27), leaf area $\left(894.5 \mathrm{~cm}^{2}\right)$, cured leaf yield $\left(3332 \mathrm{~kg} \mathrm{ha}^{-1}\right)$ reducing sugar content $(19.2 \%)$ and lower nicotine content $(2.81 \%)$, also heavier leaves with more mass were obtained for this hybrid and therefore provided the least no. of green leaves $\mathrm{kg}^{-1}$ (22.7) and no. of cured leaves kg${ }^{1}$ (163.7). Hence it is concluded and suggested from this experiment that the FCV tobacco hybrid PVH-2310 performed better as compared to other hybrids in agro-climatic condition of Mardan.

Keywords: FCV tobacco; Hybrids; Significant; Yield; Quality

\section{Introduction}

Evolution of high yielding tobacco varieties and improvement in leaf quality will fetch towards increase income to the growers and enhance exports of tobacco and its products. Our farmers are getting low yield and poor quality of tobacco in comparison with other countries of the world. One of the main 
reasons is lack of appropriate tobacco varieties which needs to be addressed and it will significantly increase production per unit area [1]. The major tobacco producing areas of Khyber Pukhtunkhwa are Swabi, Mardan, Hazara, Buner and Malakand Agency [2]. Our farmers are getting poor yield of tobacco than advanced countries of the world. One of the prevailing constraints is the lack of appropriate tobacco varieties, which needs to be addressed appropriately for getting high production per unit area [3]. Tobacco is one of the few plants entering into the world trade entirely on leaf basis and most commonly grown commercial non-food plant in the world [4]. Leaf is the major economic part of the crop, harvested for processing of cigarette industry.

The yield of tobacco can be increased by different ways. The most simple and straight options is "appropriate hybrid" which can increase yield and also has a major effect on quality as genetic materials of a cultivar play a vital role in yield and quality of a crop. Those verities should be cultivated which gives high yield with respect to regional agro-meteorological conditions.[5] Investigated that many of the researchers has given reports about variations in the genetic constitution of tobacco genotypes which are responsible for their different quantitative and qualitative performance. [6] Observed in his experiment that selection of a suitable hybrid is a key to have improved yield and quality of FCV tobacco. For addressing the said problem a varietal trial was performed to study the performance of different tobacco (FCV) hybrids in order to investigate the morpho-agronomic and quality traits of different FCV tobacco hybrids and to identify the most suitable hybrid for the agro-ecological conditions of Mardan (Pakistan).

\section{Meterials and methods \\ Experimental site}

Tobacco research station is located in the south west of the district Mardan (Pakistan) at $34^{\circ} 12^{\prime} 0 \mathrm{~N} 72^{\circ} 1^{\prime} 60 \mathrm{E}$ and an altitude of 283 meters $(928 \mathrm{ft})$, with the elevation 314 meters.

\section{Experimental design}

The experiment was laid out in RCB design having ten (10) tobacco genotypes replicated three times at the Tobacco Research Station, Khan Garhi, Mardan during 2014-15.

\section{Nursery management}

Nursery was raised on $20^{\text {th }}$ December 2014. Seed rate of $4-5 \mathrm{gm} \mathrm{ha}^{-1}$ was used. Bed size was kept $10 \mathrm{~m}$ long and $1 \mathrm{~m}$ wide. Thinning was done 4 times from 15 to 20 January. Ten different tobacco hybrids CSC-4302, CSC 447, CSC 4703, CSC-444, Spt-G-28, K-399, PVH-2310, PVH-2275, PVH-2261, PVH2233, were sown.

\section{Field preparation}

Before transplantation land preparation was done using cultivator and rotavator. Good and viable seedlings were transplanted at that same day in the field and irrigation was applied to establish good root system.

\section{Transplantation}

Transplantation was done on $18^{\text {th }}$ March 2015. Plot size was kept as $24 \mathrm{~m}^{2}$. Rows were spaced 3 feet while plant to plant distance was kept as 2 feet.

\section{Field management}

After transplantation irrigations were applied 6-7 times. N: P: K fertilizers were applied with the rate of $75: 75: 75 \mathrm{~kg} \mathrm{ha}^{-1}$. After transplantation one dose was applied to the two sides of the plants. The topping was done at buttal stage for all the hybrids and was treated with recommended suckericide. Harvesting of tobacco was completed in total of five pickings. 


\section{Suckericide used}

For the removal of suckers OUTPUT suckericide was used at rata of $10 \mathrm{ml} / 100 \mathrm{ml}$ water and was applied to each plant from top to bottom.

\section{Parameters on which data were recorded}

Data were recorded on eight quantitative parameters including plant height $(\mathrm{cm})$, number of leaves plant ${ }^{-1}$, leaf area $\left(\mathrm{cm}^{2}\right)$, no. of green leaves $\mathrm{kg}^{-1}$, no. of cured leaves $\mathrm{kg}^{-1}$ and cured leaf yield $\left(\mathrm{kg} \mathrm{ha}^{-1}\right)$ by using the standard data recording procedures and two qualitative parameters including nicotine content $(\%)$ by following the procedure of [7] and reducing sugar content (\%) by following the procedure described by [8]. After collecting the data, it was subjected to analysis of variance (ANOVA) in a procedure relevant to RCB design. The least significant difference (LSD) test was used upon significant F-Test to find results from the data and to identify the significance among the treatment means [9].

\section{Results and discussion}

\section{Plant height (cm)}

Statistical analysis of variance showed highly significant $(\mathrm{P}<0.01)$ among plant height values of different FCV hybrids. Data regarding plant height is shown in Table 1. Mean values for plant height ranged from $103.4 \mathrm{~cm}$ to $131.8 \mathrm{~cm}$. Taller plants were recorded by genotype PVH-2310 $(131.8 \mathrm{~cm})$ closely followed by K-399 $(128 \mathrm{~cm})$ which is statistically at par with PVH-2233 (126 $\mathrm{cm})$ while the shorter plants were recorded in case of CSC-447 (103.1). Differences in genetic constitution of FCV hybrids might be the reason for bringing significant variations in plant height and $\mathrm{PVH}-2310$ performed well in that sense. These results resemble to those of $[10,11]$ who also found that PVH-2310 resulted in taller plants.

Table 1. Plant height (cm), No. of leaves plant ${ }^{-1}$, Leaf area $\left(\mathrm{cm}^{2}\right)$, No. of green leaves $\mathrm{kg}^{-1}$ and No. of cured leaves $\mathrm{kg}^{-1}$ of ten FCV tobacco hybrids

\begin{tabular}{|l|l|l|l|l|l|}
\hline $\begin{array}{l}\text { Tobacco } \\
\text { Hybrids }\end{array}$ & Plant Height & $\begin{array}{l}\text { No. of Leaves } \\
\text { Plant }^{-1}\end{array}$ & $\begin{array}{l}\text { Leaf Area } \\
\left(\mathbf{c m}^{\mathbf{2}}\right)\end{array}$ & $\begin{array}{l}\text { No. of Green } \\
\text { Leaves kg }^{-1}\end{array}$ & $\begin{array}{l}\text { No. of Cured } \\
\text { Leaves kg }^{-1}\end{array}$ \\
\hline CSC-447 & $103.1 \mathrm{~h}$ & $23.3 \mathrm{e}$ & $571.8 \mathrm{i}$ & $26.7 \mathrm{a}$ & $194.7 \mathrm{a}$ \\
\hline CSC-444 & $114.3 \mathrm{ef}$ & $24.7 \mathrm{cde}$ & $699.3 \mathrm{f}$ & $25.3 \mathrm{bc}$ & $185.7 \mathrm{c}$ \\
\hline CSC-4703 & $107.3 \mathrm{~g}$ & $24.3 \mathrm{de}$ & $604.2 \mathrm{~h}$ & $25.7 \mathrm{~b}$ & $189.7 \mathrm{~b}$ \\
\hline CSC-4302 & $111.4 \mathrm{f}$ & $24.3 \mathrm{de}$ & $641.6 \mathrm{~g}$ & $25.3 \mathrm{bc}$ & $186.7 \mathrm{c}$ \\
\hline PVH-2310 & $131.8 \mathrm{a}$ & $27.0 \mathrm{a}$ & $894.5 \mathrm{a}$ & $22.7 \mathrm{~g}$ & $163.7 \mathrm{~h}$ \\
\hline PVH-2261 & $117.3 \mathrm{de}$ & $25.0 \mathrm{~cd}$ & $720.7 \mathrm{ef}$ & $24.7 \mathrm{~cd}$ & $182.3 \mathrm{~d}$ \\
\hline PVH-2233 & $126.0 \mathrm{~b}$ & $26.0 \mathrm{abc}$ & $795.7 \mathrm{c}$ & $23.7 \mathrm{ef}$ & $172.7 \mathrm{f}$ \\
\hline PVH-2275 & $122.4 \mathrm{c}$ & $26.0 \mathrm{abc}$ & $774.3 \mathrm{~cd}$ & $24.3 \mathrm{de}$ & $177.3 \mathrm{e}$ \\
\hline K-399 & $128.0 \mathrm{~b}$ & $26.7 \mathrm{ab}$ & $831.4 \mathrm{~b}$ & $23.3 \mathrm{fg}$ & $169.0 \mathrm{~g}$ \\
\hline SPT-G-28 & $120.1 \mathrm{~cd}$ & $25.3 \mathrm{bcd}$ & $749.7 \mathrm{de}$ & $24.3 \mathrm{de}$ & $179.0 \mathrm{e}$ \\
\hline LSD 0.05 & 3.486672 & 1.387673 & 29.9958 & 0.96248 & 2.866607 \\
\hline
\end{tabular}

\section{Number of leaves plant $\mathbf{t}^{-1}$}

Analysis of variance revealed significant difference at $(\mathrm{P}<0.01)$ among the FCV hybrids for number of leaves plant ${ }^{-1}$. Data regarding number of leaves per plant is presented in Table 1 which ranged from 23 to 27 number of leaves plant ${ }^{-1}$. The highest mean value for number of leaves plant ${ }^{-1}$ was recorded by hybrid PVH-2310 (27) followed by the hybrid K-399 (26.7) while the least value for number of leaves plant ${ }^{-1}(23.3)$ was recorded in by CSC-447. Significant differences among the number of leaves may be attributed to differences in the genetic potentials of FCV hybrids. Our results are in lined with that of $[12,13]$ who also found significant differences for number of leaves plant $^{-1}$ of different FCV genotypes. 


\section{Leaf area $\left(\mathrm{cm}^{2}\right)$}

Data regarding leaf area is presented in Table 1. Statistical analysis of the data showed leaf area $\left(\mathrm{cm}^{2}\right)$ has significantly affected by FCV tobacco hybrids. Leaf area of all the studied genotypes ranged from $571.8 \mathrm{~cm}^{2}$ to $894.5 \mathrm{~cm}^{2}$. The most expanded leaves were recorded by hybrid PVH-2310 $\left(894.5 \mathrm{~cm}^{2}\right)$ followed by hybrid K-399 (831.4) while comparatively the smallest leaves were recorded CSC-447 $\left(571.8 \mathrm{~cm}^{2}\right)$. The possible reason for higher leaf area could be due to higher genetic efficiency of the PVH-2310 hybrid for nutrients uptake and synthesizing building material. Hybrids with more leaf area usually have more positive effect on tobacco yield. [13] also found significant variations among the leaf area of different cultivars of tobacco they studied.

\section{Number of green leaves $\mathbf{~ k g}^{-1}$}

Data regarding green leaves $\mathrm{kg}^{-1}$ is presented in Table 1. Analysis of variance showed highly significant $(\mathrm{p}<0.01) \quad$ difference among the different hybrids for number of green leaves $\mathrm{kg}^{-1}$. Number of green leaves $\mathrm{kg}^{-1}$ were ranged from 22.7 to 26.7. More number of green leaves $\mathrm{kg}^{-1}$ by hybrid CSC447 (26.7) followed by that of CSC-4703 (25.7) whereas the lowest number of green leaves in one $\mathrm{kg}$ mass of tobacco was recorded by PVH-2310 (22.7). Less number of leaves $\mathrm{kg}^{-1}$ shows more amounts of nutrients present in the leaf. Variations among the green leaf number $\mathrm{kg}^{-1}$ might be the result of genetic variations among the studied genotypes so that there may be different genetic potential of each FCV hybrid to accumulate nutrients and mass in its leaves due to which their leaves exhibited varied masses leaded to different number of leaves $\mathrm{kg}^{-1}$ of tobacco green leaf mass. These results are in resemblance with the findings of $[14,15]$ who also found significant variations in this parameter of tobacco.

\section{Number of cured leaves $\mathbf{~ k g}^{-1}$}

Data regarding number of cured leaves per $\mathrm{kg}$ is shown in Table 1. Statistical analysis of the data showed that influence of genotypes has highly significant effect on number of cured leaves $\mathrm{kg}^{-1}$ of tobacco. Data for number of cured leaves $\mathrm{kg}^{-1}$ varied from 163.7 to 194.7. The highest mean value for cured leaves $\mathrm{kg}^{-1}$ was observed by CSC-447 (194.7) followed by CSC-4703 (189.7) and lower number of cured leaves $\mathrm{kg}^{-1}$ was observed by PVH-2310 (163.7). Different genetic capability to collect nutrients and to achieve leaf mass might be the reason for variations among the cured leaf number $\mathrm{kg}^{-1}$ of FCV tobacco hybrids kept under study. The findings are in lined with that of [14, 15] also found significant variations among the cured leaves $\mathrm{kg}^{-1}$ of different hybrids of tobacco they studied.

\section{Cured leaf yield $\left(\mathrm{kg} \mathrm{ha}^{-1}\right)$}

Data regarding cured leaf yield $\left(\mathrm{kg} \mathrm{ha}^{-1}\right)$ is shown in Table 2. Statistical analysis of the data Cured leaf yield $\left.(\mathrm{kg} \mathrm{ha})^{-1}\right)$ had significantly affected by different FCV tobacco hybrids. Mean values for yield of FCV tobacco hybrids were ranged from $2009 \mathrm{~kg} \mathrm{ha}^{-1}$ to $3332 \mathrm{~kg} \mathrm{ha}^{-1}$. The FCV hybrid PVH-2310 performed better on yield basis among all hybrids and provide higher cured leaf yield of $3332 \mathrm{~kg} \mathrm{ha}^{-1}$ followed by K-399 (3087 $\mathrm{kg} \mathrm{ha}^{-1}$ ) while the yield performance of CSC-447 was found poor which resulted in cured leaf yield of $2009 \mathrm{~kg}$ $\mathrm{ha}^{-1}$. This may attributed to genetic capability of the hybrid to accumulate and produce more yields in the available set of ecological conditions. Findings of $[16,17]$ support and agree these results that also manifested significant variations among the cured leaf yield of different genotypes. 
Table 2. Reducing sugar content (\%), Nicotine content (\%), and cured leaf yield (kg ha-1) of ten FCV tobacco hybrids

\begin{tabular}{|l|l|l|l|}
\hline Tobacco hybrids & $\begin{array}{l}\text { Reducing sugar } \\
\text { content } \mathbf{( \% )}\end{array}$ & $\begin{array}{l}\text { Nicotine content } \\
(\mathbf{\%})\end{array}$ & $\begin{array}{l}\text { Cured leaf yield } \\
\left.\mathbf{k g ~ h a}^{-1}\right)\end{array}$ \\
\hline CSC-447 & $15.6 \mathrm{i}$ & $2.44 \mathrm{i}$ & $2009 \mathrm{j}$ \\
\hline CSC-444 & $16.9 \mathrm{f}$ & $2.56 \mathrm{f}$ & $2290 \mathrm{~g}$ \\
\hline CSC-4703 & $16.3 \mathrm{~h}$ & $2.49 \mathrm{~h}$ & $2100 \mathrm{i}$ \\
\hline CSC-4302 & $16.5 \mathrm{~g}$ & $2.52 \mathrm{~g}$ & $2205 \mathrm{~h}$ \\
\hline PVH-2310 & $19.2 \mathrm{a}$ & $2.81 \mathrm{a}$ & $3332 \mathrm{a}$ \\
\hline PVH-2261 & $17.3 \mathrm{e}$ & $2.61 \mathrm{e}$ & $2484 \mathrm{f}$ \\
\hline PVH-2233 & $18.5 \mathrm{c}$ & $2.74 \mathrm{~b}$ & $2852 \mathrm{c}$ \\
\hline PVH-2275 & $18.0 \mathrm{~d}$ & $2.70 \mathrm{c}$ & $2700 \mathrm{~d}$ \\
\hline K-399 & $18.8 \mathrm{~b}$ & $2.76 \mathrm{~b}$ & $3087 \mathrm{~b}$ \\
\hline SPT-G-28 & $17.7 \mathrm{~d}$ & $2.65 \mathrm{~d}$ & $2591 \mathrm{e}$ \\
\hline LSD 0.05 & 0.265543 & 0.024237 & 58.39544 \\
\hline
\end{tabular}

\section{Reducing sugar content (\%)}

Data regarding reducing sugar content $(\%)$ is showed in Table 2. Statistical analysis of the data showed that reducing sugar content (\%) is significantly affected by different of FCV tobacco hybrids. The mean values of reducing sugar content $(\%)$ ranged from $15.6 \%$ to $19.2 \%$. Highest mean value for reducing sugar content $(19.2 \%)$ was recorded by $\mathrm{PVH}-2310$ followed by of $\mathrm{K}$ $399(18.8 \%)$ while CSC-447 provided the lowest reducing sugar content $(15.6 \%)$. The reason may be the varied genetic performance of different hybrids for gaining reducing sugar content. These results are in agreement with those of $[15,18]$ who also observed significant differences for reducing sugar content of different hybrids they studied.

\section{Nicotine content (\%)}

Data regarding nicotine content of the different FCV tobacco hybrids is shown in Table 2. Statistical analysis of the data showed that nicotine content (\%) has significantly affected by different tobacco hybrids which ranged from $2.44 \%$ to 2.81 $\%$. The highest mean value for nicotine content $(2.81 \%)$ was recorded by $\mathrm{PVH}-$ 2310 followed by K-399 (2.76 \%) which was found statistically at par with that of PVH-2233 (2.74 \%) while the lowest mean value of nicotine content $(2.44 \%)$ was observed by CSC-447. The possible reason may be the differences in genetic potentials of FCV hybrids to accumulate nicotine content. Results reported by Shah et al. [18] and Pathak et al. [19] also show significant differences for nicotine contents of different tobacco genotypes.

\section{Conclusion and recommendation}

It has been concluded from the present study that comparing different tobacco hybrid can lead to the finding of the most suitable genotype for a region. By comparing different hybrids in this trial, it was found that tobacco cultivar PVH-2310 performed the best among all the studied hybrids in terms of yield and quality as well as in term of morphology so it is recommended for tobacco growers to achieve higher yield and better quality.

\section{Authors' contributions}

Conceived and designed the experiments: MR Khan, Performed the Experiments: K Shah \& M Zahid, Analyzed the Data: MN Khan \& MZ Afridi, Contributed reagents/ materials/ analysis tools: S Iqbal, SMA Shah \& R Ullah, Wrote the paper: SJ Ahmad. 


\section{References}

1. Imtiaz $\mathrm{M}$, Khan $\mathrm{P}$, Babar $\mathrm{H}$, Depar $\mathrm{N}$, Siddiqui SH \& Memon MY (2005). Mineral dietary status of some existing domestic wheat genotypes. Nucleus 42: 213-217.

2. Ali I, Muhammad A, Raza H, Aziz-UrRehman, Ihsan-Ul-Khaliq, Ihtisham M, Iqbal A \& Anees M (2014). Performance of flue cured virginia tobacco. Intl J Basic \& Appl Sci 14 (2): 1-3.

3. Yousafzai HK, Marwat KB \& Khan MA (2006). Impact of herbicides on some agronomic and chemical characteristics of flue-cured Virginia (FCV) tobacco (Nicotianatabacum L.) Songklanakarin $J$ Sci Technol 28(5): 929-935.

4. Yousafzai H.K, Marwat KB, Khan MA \& Hassan G (2007). Efficacy of some pre and post emergence herbicides for controlling weeds of FCV tobacco Nicotiana tabacum L.) in Pakistan. African Crop Sci Conf Proc (8): 1099-1103.

5. Butorac J (2000). Heterosis and Combining ability of certain chemical traits in Burley tobacco. Rostlinna Vyroba 46(5): 219-224.

6. Rangaiah S (2006). KST 26 - A promising FCV tobacco selection for yield and quality. Karnataka J Agric Sci 19(1): 121123.

7. Idrees QM \& Khan S (2001). Effect of different seedling size and NPK doses of fertilizer on the yield and quality of fluecured Virginia tobacco (Nicotiana tabaccum L.). M.Sc (Hons) Thesis, Agronomy Department, NWFP Agricultural University, Peshawar, Pakistan.

8. Pearson D (1962). The chemical analysis of food. 32-40: Gloucester Palace, London.

9. Jan MT, Shah P, Hollington PA, Khan MJ \& Sohail Q (2009) Agriculture Research: Design and Analysis a Monograph. NWFP Agricultural Univ Peshawar Pak.

10. Butorac J, Beljo J \& Gunjaca J (2004). Study of inheritance of some agronomic and morphological traits in Burley tobacco by graphic analysis of diallel cross. Plant Soil Environ 50(4): 162-167.

11. Sadeghi SM, Amin E \& Ashouri M (2012). An investigation of gene action on different traits of tobacco under Irrigated and drought stress environment. African $J$ Biotech 11(21): 4740-4751.

12. Qizar A \& Muhammad F (2014). Yield attributing traits in parents versus hybrids in FCV tobacco (Nicotiana tabacum L.). Sarhad J Agric 30(2).

13. Ahmed S, Fida M, Ahmed Q \& Khan MA (2014). Assessing genetic variation for morpho-agronomic traits of some native and exotic FCV tobacco genotypes in Pakistan. American-Eurasian J Agric \& Environ Sci 14(5): 428-433.

14. Ahmed Q \& Muhammad F (2014). Yield attributing traits in parents versus hybrids in FCV tobcco (Nicotiana tabacum L.). Sarhad J Agric 30(2): 193-201.

15. Liu FL, Li Y, Wang SQ \& Song HY (1999). Comparison of characteristics of 7 flue-cured tobacco cultivars. $J$ Henan Agric Sci 11: 13-15.

16. Subbian, P, Shanmugasundaram VS \& Palanichamy K (1994). Evaluation of improved lines and varieties of chewing tobacco in western zone of Tamil Nadu. Tob Res 20(1): 61-62.

17. Hanoomanjee P, Lalouette JA, Bachraz DY, Sukurdeep N \& Seebaluck BD (1998). Performance testing of some fluecured tobacco varieties in recent years. Proc. of the 2nd Annual Meeting of Agric. Scientists, Reduit, Mauritius 12-13 Aug.

18. Shah SMA, Ahmad A, Mohammad F, Hidayat-ur-Rahman, Woras G, Khan MY \& Jan D (2008). Genotypic evaluation of some Virginia tobacco varieties for yield and quality traits. Sarhad J Agric 24(4): 607-61.

19. Pathak HC, Patel JN, Jadeja GC, Lakshminarayana R \& Patel SB (1996). Line $\times$ tester analysis for yield and quality in tobacco (Nicotiana tabacum L.). Tob Res 22(1): 7-13. 